\title{
Management of Bakanae Disease of Rice through Combination of Trichoderma spp. and Fungicides
}

\author{
Sanchita Pal*, Kamal Khilari, Sachin Kumar Jain, Jaskaran Singh, \\ Abhishek Kumar and Anupam Kumar
}

Department of Plant Pathology, S.V.P. University of Agri. and Tech., Meerut 250110, India

*Corresponding author

\section{Keywords \\ Bakanae disease, Fusarium moniliforme, Bio- agent, Trichoderma, Nativo and Saaf \\ Article Info \\ Accepted: \\ 07 October 2019 \\ Available Online: \\ 10 November 2019}

\section{A B S T R A C T}

Bakanae disease is becoming a serious threat to basmati production and had been reported to cause $20-50 \%$ loss in total production. Bakanae disease caused by Fusarium moniliforme is an emerging and very serious problem of basmati rice. It occurs in both upland and low land rice field. The typical symptoms of the disease are abnormal elongation of seedlings, foot rot and seedling rot of rice. The pathogen survives mainly in seed and in soil also. Therefore seed treatment for the management of seed borne pathogen is most effective method of disease management. Seed treatment with bio-agent for the management of diseases is an eco- friendly method of disease management. Keeping this in view in present investigation different isolates of Trichoderma were tested in the management of bakanae disease of basmati rice as seed treatment. Trichoderma powder was applied for seed treatment @ $6 \mathrm{~g} / \mathrm{kg}$ seed alone and in combination with different fungicides $2 \mathrm{~g} / \mathrm{kg}$ seed. Experiments were conducted in pot condition. The observations were recorded on seed germination, number of tillers and disease incidence after 30 days 'of seed sowing. Two fungicides (nativo, saaf) and two isolates of Trichoderma $\left(\mathrm{S}_{1}\right.$, and $\mathrm{S}_{7}$ ) were tested in pot condition against Fusarium moniliforme. Maximum (90\%) germination was recorded in case of seed treatment with Trichoderma- $\mathrm{S}_{7}$ followed by $83.33 \%$ in Trichoderma $\mathrm{S}_{7}+$ nativo. Minimum $(22.85 \%)$ disease incidence was recorded in case of the seed treated with Trichoderma-S $\mathrm{S}_{7}$. Maximum disease incidence $(76.6 \%)$ was recorded in case of control. Among the fungicides and bio-agent, seed treatment with Trichoderma- $\mathrm{S}_{7}$ was most effective for the management of bakanae disease of rice. The selected fungicides and bio-control agents were evaluated as seed and seedling treatment for controlling bakanae disease under field conditions. Among three fungicides evaluated as seed treatment, minimum disease incidence $(0.0 \%)$ was observed in seed treatment with Tricoderma- $\mathrm{S}_{1}$ followed by seed treatment with Tricoderma $-\mathrm{S}_{1}+\mathrm{saaf}(0.1 \%)$. Maximum disease incidence was observed in the case of control $(0.75 \%)$ followed by seed treatment with Trichoderma $(0.49 \%)$. Maximum yield (40 q/ ha) was recorded in case of treatment of Trichoderma- $\mathrm{S}_{1}$ which was found most effective for the management of bakanae disease of rice. 


\section{Introduction}

Rice is an important cereal crop and growing all over the world. Rice grows in India is primarily divided into basmati rice and NonBasmati rice. India is the major producer and exporter of basmati rice to the world. Rice production affected by many biotic and abiotic stresses. Among the biotic stress, fungal diseases have important role in reduction the yield of rice. Bakanae (Foot rot) disease is one of them that is emerging as major threat to basmati rice production. Bakanae disease caused by Fusarium moniliforme Shelder [teleomorph: Gibberella fujikuroi (Saw.) Wr.] is one of the important disease of rice occurring throughout the rice growing regions of the world (Ram Singh and Sunder, 2012). It is known to cause around 15 per cent loss in Uttar Pradesh and Assam states of India (Pavgi and Singh 1964, Rathaiah et al., 1991). The fungus produces gibberellins and other secondary metabolites such as carotenoids, bikaverin and fusarin, which directly affect the growth of rice, plants (Ilija et al., 2009). The fungus produces giberrellin hormone which causes elongation of plant (Nyvall, 1999). The pathogen is widely distributed through ought the world and has wide host range (Kazempour, 2007). F. moniliforme is primarily a seed-borne pathogen which infects the seedlings at the time of germination or at an early growth stage (Ou, 1985). Injured roots have been reported to serve as potential entry source of Fusarium spp. The disease can occur both at nursery stage and in the main field. Seedlings which survive the attack in nursery may die soon after transplanting. The affected plants appear pale yellow in colour, thin and abnormally long or rarely dwarf. These plants may die prematurely or may develop tall tillers and flower earlier than the healthy plants but the infected plants mostly bear sterile panicles. Highly diseased plants show collar infection and die within 2-6 weeks. There is profuse branching in the roots and adventitious roots may develop from the lower nodes. A pinkish white cottony growth of the fungal mycelium may be observed at the base of the plant. The fungus produces growth stimulating substances known as gibberellins, which is responsible for excessive elongation of the plants (Malonek et al., 2005). Besides gibberellins, the fungus also produces a phytotoxin, fusaric acid, a nonspecific substance which is toxic to the plants (Desjardins et al., 2000). Seed treatment with fungicide such as thiram has been used for management of bakanae disease (Suzuki et al., 1985). So, there was a dire need of comprehensive studies on the management of this disease. Hence, an study was conducted, using bio-agents and combination of bio-agents and chemical as seed treatments for the management of bakanae disease in basmati rice (var. PB1121).

\section{Materials and Methods}

\section{Mass multiplication and preparation of Trichoderma spp.}

The bio-control agent Trichoderma isolates $\left(\begin{array}{lll}\mathrm{S}_{1} & \& & \left.\mathrm{~S}_{7}\right)\end{array}\right)$ were collected from Nematology Lab, Department of Plant Pathology Sardar Vallabhbhai Patel University of Agriculture and Technology, Meerut U.P. Wheat grains were used for mass culture of Trichoderma. Wheat grains were soaked in water for 12 hours and then spreaded on paper to remove the extra water. Dextrose was added in wheat seeds @ 2 gm $/ \mathrm{kg}$ seed and then $250 \mathrm{gm}$ of wheat grains were taken in each $500 \mathrm{ml}$ conical flasks. Flasks with wheat grains were plugged with nonabsorbent cotton and wrapped with aluminum foil and sterilized in autoclave at $121^{\circ} \mathrm{C}$ temperature at $15 \mathrm{lbs}$ pressure/inch for 15 minutes. The sterilized wheat grains were inoculated by taking $5 \mathrm{~mm}$ diameter PDA disc from the periphery of actively growing 5 days old culture of Trichoderma isolates. All the inoculated 
conical flasks were incubated in incubator at $26 \pm 2^{\circ} \mathrm{C}$ temperature. These inoculated flasks were allowed to grow Trichoderma with periodic shaking of the flasks, so that the surface of all wheat seeds colonized with growth of Trichoderma properly. After proper growth of Trichoderma on the surface of wheat grain in conical flask (when colure of fungal growth become fully green) whole grains were taken out from flask, and spreaded in neat and clean plastic trays, clumps of grains were broken, then after fungal growth covered grain were shade air dried, after proper drying grains were converted in fine powder with the help of mixer grinder and pestle mortar. This fine powder was used for seed treatment for conducting trails. At the time of seed treatment this powder@6 $\mathrm{gram} / \mathrm{kg}$ seed was applied for seed treatment.

\section{Pot experiment}

A pot experiment was conducted to see the Effect of application of Trichoderma isolates alone and in combination of fungicides on the management of bakanae disease of basmati rice. In this experiment first seed were inoculated with pathogen inoculums by soaking the seeds overnight in pathogen culture suspension. Followed by these seeds were treated with bio-agents and chemicals as per plan. Ten seeds were sown in the each earthen pot. The each treatment was replicated three times, control pots were maintained without seed treatment with bio-agent but these seeds were inoculated with pathogen. The observations were recorded on seed germination, no. of tillers and disease incidence after 30 days of sowing. Data on number of bakanae infected plants were recorded at 30 days after sowing.

\section{Field experiment}

A field Trail was conducted at CRC to see the performance of Trichoderma isolates alone and in combination of fungicides in the management of bakanae disease of rice. In this experiment two isolates of Trichoderma $\left(\mathrm{S}_{1} \&\right.$ $\mathrm{S}_{7}$ ) and three different fungicides (saaf, nativo and bavistin) were taken in different combinations for the seed treatment. Trichoderma @ $6 \mathrm{gm} / \mathrm{kg}$ of seed and chemicals@ $2 \mathrm{gm} / \mathrm{kg}$ of seed were applied for seed treatment. Observations on bakanae disease incidence at 30 days after transplanting and yield/plot were recorded. The present disease incidence was calculated according to the following formula given by (Teng and james, 2001; Zainudin et al., 2008)

Percent disease incidence

Total number of infected plant

$=\frac{\text { Total plant examined }}{100}$

\section{Results and Discussion}

In pot condition, maximum (90\%) germination was recorded in case of Trichoderma- $\mathrm{S}_{7}$ followed by $83.33 \%$ in Trichoderma$\mathrm{S}_{7}+$ Nativo.While $(76.6 \%)$ germination was recorded in case of seed treatment with Trichoderma- $\mathrm{S}_{7}+$ Saaf. $\quad$ Maximum 9 tillers/plant were recorded in seed treatment with Trichoderma- $\mathrm{S}_{7}$ followed by 7.33 tillers/plant recorded in case of seed treated with Trichoderma- $\mathrm{S}_{1}+$ Nativo, Trichoderma$\mathrm{S}_{7}+$ Nativo and Trichoderma- $\mathrm{S}_{7}+\mathrm{Saaf}$ respectively. In case of control 5.33 tillers/plants were recorded. Minimum $(22.85 \%)$ disease incidence was recorded in case of seed treated with Trichoderma- $\mathrm{S}_{7}$ followed by $35.30,37.52$ and $38.33 \%$ disease incidence was recorded in case of seed treated with Trichoderma- $\mathrm{S}_{1}+\mathrm{Nativo}$, Nativo alone and Trichoderma $\mathrm{S}_{7}+$ Nativo respectively. Maximum $76.6 \%$ disease incidence was recorded in case of control.

In the field condition, minimum disease incidence $(0.0 \%)$ was observed in seed 
treatment with Tricoderma- $\mathrm{S}_{1}$ followed by seed treatment with Tricoderma- $\mathrm{S}_{1}+$ saaf $(0.1 \%)$ and in treatment Tricoderma- $\mathrm{S}_{7}$ and Trichoderma- $\mathrm{S}_{7}+$ saaf it was $0.2 \%$. Maximum disease incidence $(0.75 \%)$ was recorded in case of control followed by in Trichoderma$\mathrm{S}_{7}+$ nativo $(0.49 \%)$. Maximum yield (40 q/ ha) was recorded in case of treatment with Trichoderma- $\mathrm{S}_{7}$. In field condition seed treatment with Trichoderma- $\mathrm{S}_{7}$ was found most effective for the management of bakanae disease of rice (Fig. 1 and 2; Table 1 and 2).

Table.1 Management of bakanae disease of rice in pot condition

\begin{tabular}{|c|c|c|c|c|c|c|}
\hline Treatment & Treatments & $\begin{array}{c}\% \text { seeds } \\
\text { germination }\end{array}$ & $\begin{array}{l}\text { Healthy } \\
\text { plants at } \\
\text { 30 days }\end{array}$ & $\begin{array}{l}\text { Infected } \\
\text { Plants at } \\
\text { 30 days }\end{array}$ & $\begin{array}{l}\text { Total no } \\
\text { of Tillers } \\
\text { per plant }\end{array}$ & $\begin{array}{c}\text { Disease } \\
\text { incidence }(\%) \text { at } \\
30 \text { days }\end{array}$ \\
\hline $\mathbf{T}_{1}$ & $\begin{array}{l}\text { Seed treatment with } \\
\text { Trichoderma- } \mathrm{S}_{1}\end{array}$ & 73.20 & 5.3 & 2.00 & 6.67 & 54.05 \\
\hline $\mathbf{T}_{2}$ & $\begin{array}{l}\text { Seed treatment with } \\
\text { Trichoderma- } \mathrm{S}_{7}\end{array}$ & 90.00 & 7.0 & 1.60 & 9.00 & 22.85 \\
\hline $\mathbf{T}_{\mathbf{3}}$ & $\begin{array}{l}\text { Seed treatment with } \\
\text { Trichoderma- } \mathrm{S}_{1}+\text { nativo }\end{array}$ & 86.60 & 6.6 & 2.33 & 7.30 & 35.30 \\
\hline $\mathbf{T}_{4}$ & $\begin{array}{l}\text { Seed treatment with } \\
\text { Trichoderma-S } \mathrm{S}_{7}+\text { nativo }\end{array}$ & 83.30 & 6.0 & 2.30 & 7.30 & 38.33 \\
\hline $\mathbf{T}_{5}$ & $\begin{array}{l}\text { Seed treatment with } \\
\text { Trichoderma- } \mathrm{S}_{7}+\text { saaf }\end{array}$ & 76.60 & 4.0 & 2.30 & 7.30 & 57.50 \\
\hline $\mathbf{T}_{6}$ & $\begin{array}{l}\text { Seed treatment with } \\
\text { Trichoderma- } \mathrm{S}_{1}+\text { saaf }\end{array}$ & 66.00 & 5.3 & 3.00 & 6.00 & 56.60 \\
\hline $\mathbf{T}_{7}$ & $\begin{array}{l}\text { Seed treatment with nativo } \\
\text { only }\end{array}$ & 53.00 & 5.3 & 2.00 & 6.67 & 37.52 \\
\hline \multirow[t]{2}{*}{$\mathbf{T}_{8}$} & Control & 50.00 & 3.0 & 2.30 & 5.33 & 76.60 \\
\hline & C.D at $5 \%$ & 1.886 & 1.817 & N.S & N.S & N.S \\
\hline
\end{tabular}

Table.2 Management of bakanae disease of basmati rice in field condition

\begin{tabular}{|c|c|c|c|c|c|c|}
\hline Treatment & Treatments & $\begin{array}{c}\text { Healthy } \\
\text { plant }\end{array}$ & $\begin{array}{c}\text { Infected } \\
\text { plant }\end{array}$ & $\begin{array}{c}\text { Disease } \\
\text { incidence } \\
(\%)\end{array}$ & $\begin{array}{c}\text { Yield/ } \\
\text { plot } \\
(\mathrm{Kg})\end{array}$ & $\begin{array}{l}\text { Yield } \\
\text { q/ha }\end{array}$ \\
\hline $\mathbf{T}_{1}$ & Seed Treatment with Trichoderma $-\mathrm{S}_{1}$ & 540 & 0.0 & 0.00 & 4.5 & 37.50 \\
\hline $\mathbf{T}_{2}$ & Seed Treatment with Trichoderma- $\mathrm{S}_{7}$ & 537 & 1.0 & 0.20 & 3.5 & 29.16 \\
\hline $\mathbf{T}_{3}$ & Seed Treatment with Trichoderma- $\mathrm{S}_{1}+$ saaf & 538 & 0.6 & 0.10 & 3.5 & 29.16 \\
\hline $\mathbf{T}_{4}$ & Seed Treatment with Trichoderma- $\mathrm{S}_{7}+$ saaf & 537 & 1.3 & 0.20 & 2.5 & 20.83 \\
\hline $\mathbf{T}_{5}$ & Seed Treatment with Trichoderma- $\mathrm{S}_{1}+$ nativo & 528 & 1.3 & 0.25 & 4.2 & 35.00 \\
\hline $\mathbf{T}_{6}$ & Seed Treatment with Trichoderma-S $\mathrm{S}_{7}+$ nativo & 534 & 2.6 & 0.49 & 3.7 & 30.83 \\
\hline $\mathbf{T}_{7}$ & Seed Treatment with Trichoderma- $\mathrm{S}_{1}+$ bavisten & 533 & 2.0 & 0.37 & 4.8 & 40.00 \\
\hline $\mathbf{T}_{8}$ & Seed Treatment with Trichoderma- $\mathrm{S}_{7}+$ bavistin & 532 & 2.0 & 0.37 & 4.0 & 33.33 \\
\hline \multirow[t]{2}{*}{$\mathbf{T}_{9}$} & Control & 536 & 4.0 & 0.75 & 3.7 & 30.83 \\
\hline & C.D at $5 \%$ & 1.307 & 2.128 & - & - & \\
\hline
\end{tabular}


Fig.1 Effect of different treatments on management of bakanae disease
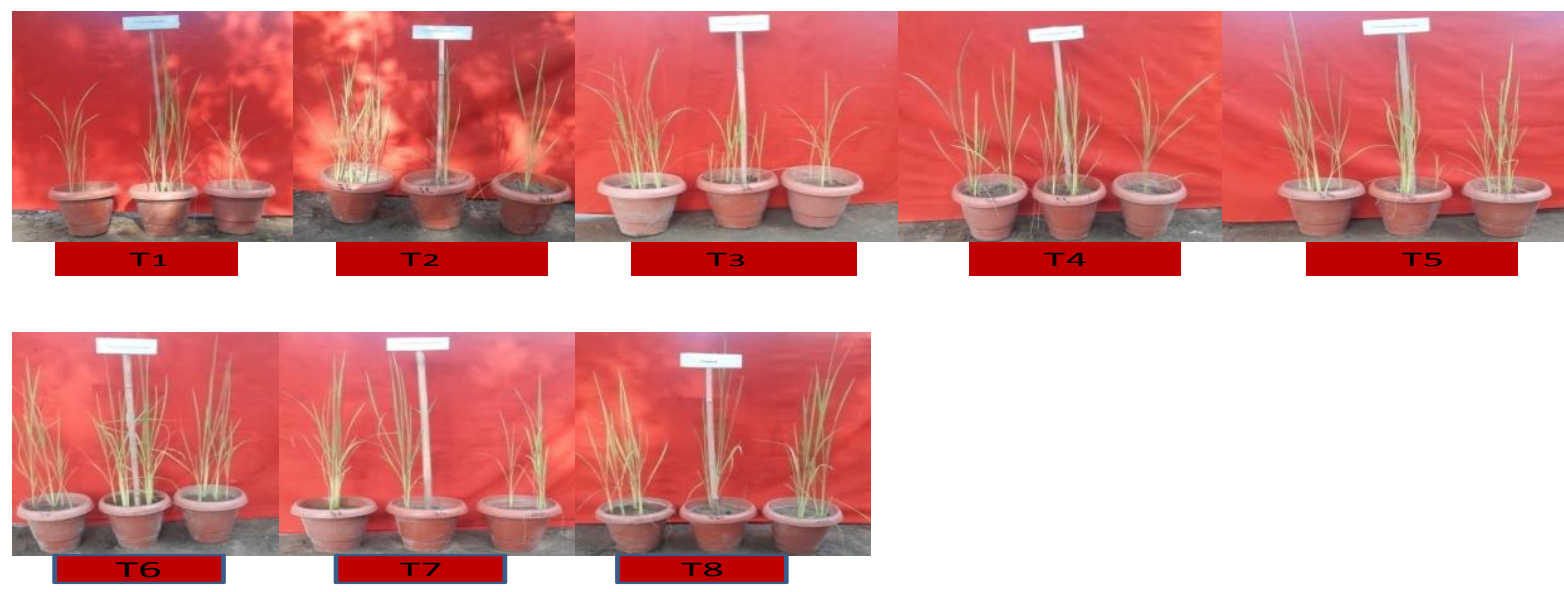

Fig.2 View of the field experiment (plots wise)

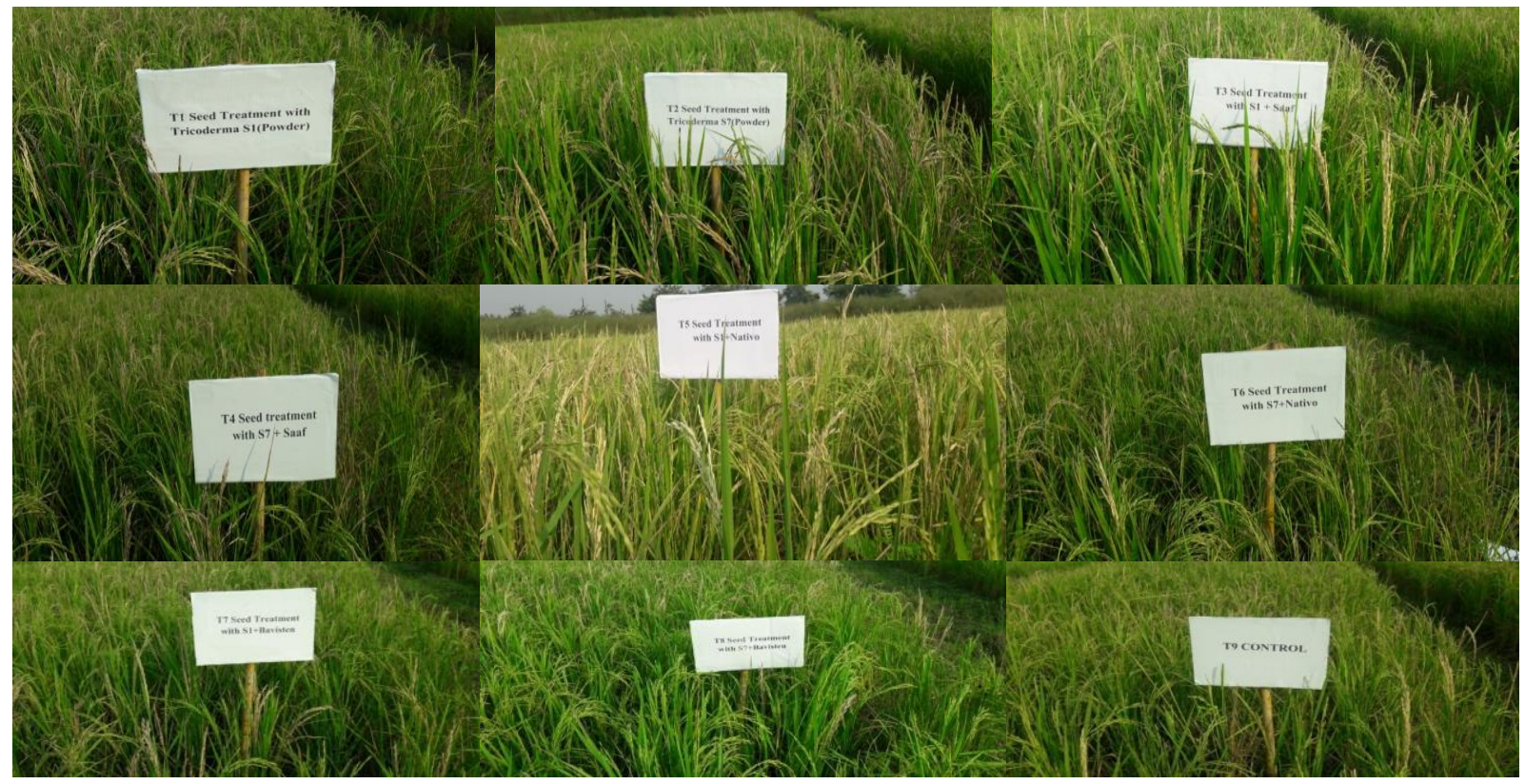

As the disease has been reported mainly seed borne in nature (Webster and Gunnell, 1992), therefore seed treatment may be an effective way for the management of pathogen of the bakanae disease. Seed treatment with chemical had been found effective by different worker in the management of this disease. Bagga and Sharma (2006) evaluated different fungicides as seed treatment for controlling bakanae disease in basmati rice. They reported that seed treatment with bavistin at the rate of $0.1 \%$ for $6 \mathrm{~h}$ was effective in reducing the disease incidence. They also reported that during seed treatment fungicide efficacy increased as the duration of the treatment increased from 2-6 hours. During their study Bhalli et al., (2001) found Derosal fungicide (Carbendazim) most effective against 
Fusarium moniliforme causing bakanae disease of rice. There are several reports where Trichoderma has been found effective bioagent for the management of Fusarium spp. The isolates S-1 \& S-7 of Trichoderma selected in this study for seed treatment were also found quite effective in previous in vitro studies. For reducing the doze of chemical pesticides in the management of this disease and for getting sustainable management thase isolates were tried for seed treatment alone and in combination of fungicides. Similar to this study,biobased options had been tried by different workers and some level of success has been obtained for the management of this disease. Fusarium moniliforme causing foot rot/bakanae disease of rice was controlled biologically using fermented products of composts and vermicompost by (Manandhar and Yami 2008).

Trichoderma species as potential bio-agents for the management of several plant diseases has been reported by several workers.

The biocontrol potential of Trichoderma spp. against phytopathogenic Fusarium spp was reported by Calistru et al., (1997). Trichoderma species are commonly used for effective management of fungal pathogen in various fruit crops (Svetlana et al., 2010). Dehkaei et al., (2004) reported that $T$. harzianum, $T$. virens were found most effective boi-agents to reduce the bakanae disease of rice. Bhramaramba, et al., (2013) reported that twenty eight Trichoderma isolates were collected from the major rice growing areas of Nalgonda, Krishna and Khammam districts of Andhra Pradesh belonged to seventeen species. These isolates were found effective in vitro against the Fusarium fujikuroi to reduce growth of pathogen. Application of Trichoderma in combination with fungicide as seed treatment may have a synergistic effect on management of bakanae disease. In early stage of seed germination chemical provide the protection to the seedling and later on Trichoderma proliferate in the rhizosphere and provides the protection to the plant from pathogen.

On the bases of the results of present investigations it can be concluded that application of Trichoderma as seed treatment alone and in combination of fungicides may be recommended for the management of bakanae disease in rice.

\section{Acknowledgment}

Authors wish to thank UPCST, Lucknow for financial support for conducting research work on management of bakanae disease of rice and also highly thankful to Hon'ble Vice Chancellor, SVPUA\&T Meerut for encouraging and providing necessary facilities to carry out this research work.

\section{References}

Anonymous 1977. Annual report for 1974-75. Mimeographed Paper, BRRI, Joydebpur, Dacca. Pp. 64-65.

Aurangzeb M., Ahmad, J. and Ilyas, M. B. 1998. Chemical control of bakanae disease of rice caused by Fusarium moniliforme. Pakistan J. Phytopathol. 10(1): 14-17.

Bhramaramba, S. and Nagamani, A. 2013. Antagonistic Trichoderma isolates to control bakanae pathogen of rice. Agric. Sci. Digest., 33 (2): 104 - 108.

Bonanomi, G., Antignani, V., Pane, C. and Scala, E. 2007. Suppression of soil borne fungal diseases with organic amendments. J. Plant Pathol., 89: 311324.

Calistru, C., McLean M. and Berjak, P. 1997. In vitro studies on the potential for biological control of Aspergillus flavus and Fusarium moniliforme by Trichoderma species. Mycopathologia, 137: 115-124. 
Desjardins, A. E., Manandhar, H. K. Plattner, R. D. Manandhar, G. G., Poling, S. M. and Maragos, C. M. 2000. Fusarium species from nepalese rice and production of mycotoxins and gibberellic acid by selected species. Applied Environ.

Dehkaei, F. P. Jajaei, S. M. and Rouhani, H. 2004. Effects of paddy soil antagonistic micro-organisms of Guilan on the causal agent of rice bakanae disease. Journal of Science and Technology Agriculture and Natural Resourse; 8: 213-22.

Hossain M. A., Latif, M. A., Kabir, M.S., Kamal, M. M., Mian M. S., Akter, S. and Sharma, N. R. 2007. Dissemination of integrated disease management practices through farmers' participatory field trial. A Report on Agricultural Technology Transfer (ATT) Project. Bangladesh Agricultural Research Council, New Airport Road, Dhaka-1215.

Ilija, K. K., Sasa, K. M. and Emilija, D. K. 2009. Gibberella fujikuroi (Sawada) Wollenweber, the new parasitical fungus on rice in the Republic of Macedonia. pp.175-182.

Kamil, D., Kumar, R. and Sinha, A. 2009. Effect of green manuring of Crotolaria juncea L. on some soil-borne pathogens. Indian Phytopathol., 62: 304-309.

Kazempour, M. N. and Elahinia, S. A. 2007. Biological control of Fusarium fujikuroi, the causal agent of Bakanae disease by rice associated antagonistic bacteria. Bulgarian J. Agric. Sci., 13(4): 393- 408.

Malonek, S., C. Bomke, E. Bornberg-Bauer, M.C. Rojas, P. Hedden, P. Hopkins and Tudzynski, B. 2005. Distribution of gibberellin biosynthetic genes and gibberellin production in the Gibberella fujikuroi species complex.
Phytochemistry, 66: 1296-1311.

Manandhar, T. and Yami, K. D. 2008. Biological control of foot rot disease of rice using fermented products of compost and vermicompost. Scient. World, 6: 52-57.

Marzano, S. Y. 2012. Assessment of disease suppression in organic transitional cropping systems. Ph.D. Thesis, University of Illinois, Urbana. Microbiol., 66: 1020-1025.

Nyvall, R. F. 1999. Field Crop Diseases. Iowa State University Press, USA. p. 1,021

Pavgi, M. S. and Singh, J. 1964. Bakanae and foot rot of rice in Uttar Pradesh, India. Plant Disease Reporter. 48: 340-342.

Rajik, M., Pathak, S. P., Biswas, S. K. and Naresh, P. R. E. M. 2011. Effect of organic amendment on soil microflora and soil borne diseases of potato. Indian Phytopathol., 64: 280-285.

Rathaiah, Y. Das, G. R. and Singh, K. H. U. 1991. Estimation of yield loss and chemical control of bakanae disease of rice. Oryza 28: 509-512.

Singh, R. and Sunder, S. 2012. Foot rot and bakanae of rice: an overview. Rev. Plant Pathol. 5: 565-604.

Suzuki, H., Takahashi, S., Fujita, Y. and Sonoda, R. 1985. Effect of seed disinfection by thiram benomyl on blast, brown spot and "Bakanae" disease of rice (in Japanese). Ann. Rep. Plant Prot. North Jpn. 36: 122-124.

Svetlana, Z., Stojanovic, S. Ivanovic, Z. Gavrilovic, V. Tatjana P. and Jelica, B. 2010. Screening of antagonistic activity of microorganisms against Colletotrichum acutatum and Colletotrichum gloeosporioides. Arch. Biol. Sci., 62: 611-623.

Teng, P. S. and James, W. C. 2001. Diseases loss assessment. In Plant Pathologist's Pocketbook' (Waller J M, Leanne J M waller, SJ Ed.). CABI Publishing Company Inc. Boston, Massacharsets. 
Pp. 25-38

Ou, S. H. 1985. Rice Diseases. 2nd Edn., Commonwealth Mycological Institute, Kew, UK., Pp. 380.

Zainudin, N. A. I. M., Razak, A. A. and Salleh, B. 2008. Bakanae Disease of rice in Malaysia and Indonesia: etiology of the causal agent based on morphological, physiological and pathogenicity characteristics. Journal of Plant Protection Research, 48 (4): 475-48
Zainudin, N. I. M., Razak A. and Salleh, B. 2008. Bakanae disease of rice in Malaysia and Indonesia: Etiology of the causal agent based on morphological, physiological and pathogenicity characteristics. J. Plant Protect. Res., 48: 475-485.

Webster, R. K. and Gunnell, P. S. 1992. Compendium of Rice Diseases. The American Phytopathological Society, St. Paul, MN., USA. Pp. 62.

\section{How to cite this article:}

Sanchita Pal, Kamal Khilari, Sachin Kumar Jain, Jaskaran Singh, Abhishek Kumar and Anupam Kumar. 2019. Management of Bakanae Disease of Rice through Combination of Trichoderma spp. and Fungicides. Int.J.Curr.Microbiol.App.Sci. 8(11): 494-501. doi: https://doi.org/10.20546/ijcmas.2019.811.060 